SHORT REPORTS

\section{Phenobarbitone elimination rate after oral charcoal}

Activated charcoal is used in treating poisoning by drugs to prevent their absorption. If given early and in a high dose $(50 \mathrm{~g})$ it will inhibit the absorption of over $90 \%$ of most drugs. ${ }^{12} \mathrm{~A}$ high proportion of many drugs with a long half life are excreted into the gut and reabsorbed.

We report on the effect of activated charcoal, given orally in high multiple doses, on the elimination rate of three drugs with a long half life: phenobarbitone, carbamazepine, and phenylbutazone.

\section{Methods and results}

Five healthy volunteers participated in the randomised cross-over study. After an overnight fast they swallowed the following drugs: $200 \mathrm{mg}$ phenobarbitone, $400 \mathrm{mg}$ carbamazepine, and $200 \mathrm{mg}$ phenylbutazone. They then received either water alone or $50 \mathrm{~g}$ activated charcoal suspended in water either within 5 minutes or 1 hour of ingesting the drugs, or they received $50 \mathrm{~g}$ activated charcoal only 10 hours after the drugs, followed by four further doses of $17 \mathrm{~g}$ at $14,24,36$, and 48 hours. Serum samples were taken $0,1,3,6,10,24,32,48,72$, and 96 hours after drug ingestion. Phenobarbitone and phenylbutazone concentrations were estimated by gas chromatography and that of carbamazepine by spectrophotometry. ${ }^{2} 3$

Drug absorption was almost completely prevented by $50 \mathrm{~g}$ charcoal taken immediately after the drugs, whereas the effect was much weaker when 1 hour elapsed between the ingestion of the drugs and the charcoal (table).

Effect of oral doses of activated charcoal on absorption and elimination of drugs (mean $\pm S E$ in five subjects)

\begin{tabular}{|c|c|c|}
\hline Drug & $\begin{array}{l}\text { Area under serum } \\
\text { concentration/time curve } \\
(\% \text { of control })\end{array}$ & $\underset{(h)}{\text { Serum half life }}$ \\
\hline \multirow{2}{*}{$\begin{array}{l}\text { Phenobarbitone } 200 \mathrm{mg}: \\
\text { without charcoal (control) } \\
+50 \mathrm{~g} \text { charcoal within } 5 \mathrm{~min} \\
+50 \mathrm{~g} \text { charcoal } 1 \mathrm{~h} \text { later } \\
+50 \mathrm{~g} \text { charcoal } 10 \mathrm{~h} \text { later and } \\
\quad 17 \mathrm{~g} 14,24,36 \text {, and } 48 \mathrm{~h} \text { later }\end{array}$} & $\begin{array}{r}100 \\
<3 \\
53\end{array}$ & $110 \pm 23$ \\
\hline & 51 & $19 \cdot 8 \pm 1 \cdot 0^{*}$ \\
\hline \multirow{2}{*}{$\begin{array}{l}\text { Carbamazepine } 400 \mathrm{mg} \text { : } \\
\text { without charcoal (control) } \\
+50 \mathrm{~g} \text { charcoal within } 5 \mathrm{~min} \\
+50 \mathrm{~g} \text { charcoal } 1 \mathrm{~h} \mathrm{later} \\
+50 \mathrm{~g} \text { charcoal } 10 \mathrm{~h} \text { later and } \\
17 \mathrm{~g} 14,24,36 \text {, and } 48 \mathrm{~h} \text { later }\end{array}$} & $\begin{array}{l}100 \\
<5 \\
59\end{array}$ & $32 \cdot 0 \pm 3 \cdot 4$ \\
\hline & 73 & $17 \cdot 6 \pm 2 \cdot 4^{*}$ \\
\hline \multirow{2}{*}{$\begin{array}{l}\text { Phenylbutazone } 200 \mathrm{mg} \text { : } \\
\text { without charcoal (control) } \\
50 \mathrm{~g} \text { charcoal within } 5 \mathrm{~min} \\
50 \mathrm{~g} \text { charcoal } 1 \mathrm{~h} \text { later } \\
50 \mathrm{~g} \text { charcoal } 10 \mathrm{~h} \text { later and } \\
17 \mathrm{~g} 14,24,36 \text {, and } 48 \mathrm{~h} \text { later }\end{array}$} & $\begin{array}{r}100 \\
2 \\
70\end{array}$ & $51 \cdot 5 \pm 7 \cdot 6$ \\
\hline & 95 & $36 \cdot 7 \pm 4 \cdot 1^{*}$ \\
\hline
\end{tabular}

*Significantly shorter than during the control period: $\mathrm{p}<0.05$.

When activated charcoal was taken 10 hours later there was hardly any interference with the absorption of any of the drugs, as judged by the high and declining serum drug concentrations. Serum phenobarbitone concentration decreased much faster when charcoal was given in multiple doses than during the control period. Moreover, carbamazepine and phenylbutazone were eliminated more rapidly when activated charcoal was given during the elimination phase.

Two of the five subjects were moderately constipated during the multiple charcoal phase but readily responded to lactulose.

\section{Comment}

The results indicate that activated charcoal given early enough and in adequate doses almost completely prevents the absorption of phenobarbitone, carbamazepine, and phenylbutazone. There was a fivefold increase in the rate of phenobarbitone elimination in response to repeated administration of activated charcoal during the elimination period. Thus most of the phenobarbitone is obviously secreted into the intestinal lumen by biliary or other routes and is reabsorbed subsequently. Charcoal prevents this absorption.

Surprisingly, the effectiveness of activated charcoal in removing phenobarbitone is not far from that of haemodialysis. The latter shortens the half life of phenobarbitone from about' 100 hours to
8 hours-that is, a single dialysis run of 6 hours removes about $40 \%$ of phenobarbitone. ${ }^{4}$ The same fraction is eliminated within 15 hours by oral activated charcoal.

Activated charcoal nearly doubled the rate of elimination of carbamazepine, an antiepileptic drug related structurally to tricyclic antidepressants. Thus their increased rate of elimination might be a response to multiple doses of activated charcoal for two to three days.

This report is concerned with the use of these drugs in therapeutic doses. In massive drug overdosage, however, the enteral recycling of drugs might be changed and hence the efficacy of charcoal might be less than we found. Nevertheless, oral charcoal in high multiple doses would almost certainly shorten the period of intoxication caused by any drug which has both a long half life and an extensive enterohepatic or enteroenteric cycle.

1 Neuvonen PJ, Elfving SM, Elonen E. Reduction of absorption of digoxin, phenytoin and aspirin by activated charcoal. Eur $\mathcal{f}$ Clin Pharmacol $1978 ; 13: 213-8$.

${ }^{2}$ Neuvonen PJ, Elonen E. Effect of activated charcoal on absorption and elimination of phenobarbitone, carbamazepine and phenylbutazone in man. Eur $\mathcal{F}$ Clin Pharmacol (in press).

${ }^{3}$ Rist Nielsen H, Remmer H. Kvantitativ bestemmelse af karbamazepin (Tegretol R) i serum. Ugeskr Laeger 1969;131:2200-1.

4 Takki S, Gambertoglio JG, Honda DH, Tozer TN. Pharmacokinetic evaluation of hemodialysis in acute drug overdose. $\mathcal{F}$ Pharmacokinet Biopharm 1978;6:427-42.

(Accepted 17 December 1979)

Department of Clinical Pharmacology, University of Helsinki, SF-00250 Helsinki 25, Finland

P J NEUVONEN, MD, senior lecturer in clinical pharmacology E ELONEN, MD, consultant in medicine and clinical pharmacology

\section{Gastrocolic fistula in debilitating Crohn's disease: value of initial loop ileostomy}

Gastrocolic fistula is a complication of gastroenterostomy for peptic ulcer. It has also been reported with gastric and colon cancer, ${ }^{1}$ isletcell tumour of the pancreas, ${ }^{2}$ benign gastric ulcer ${ }^{3}$ and gastric lymphoma and carcinoid tumour of the transverse colon. ${ }^{4}$ Reports of its occurrence in Crohn's disease of the colon are rare. ${ }^{5}$ Initial loop ileostomy in the management of gastrocolic fistula in the debilitated patient with Crohn's disease of the colon has not been reported, and we describe such a case.

\section{Case report}

A 33-year-old white man had a 15-year history of Crohn's ileocolitis. His main complaints were 10 to 20 loose bowel movements per day, pain, and excessive purulent drainage in the perirectal region. He had lost $13.6 \mathrm{~kg}$ in the few weeks before admission and had had foul-smelling eructations. He was severely malnourished, while abdominal examination showed only scars of incisions from previous drainage of a right-sided abdominal abscess and a left inguinal herniorrhaphy. He had a large horseshoe anal fistula with bilateral ischiorectal abscesses. Proctoscopy showed anal and rectal stenosis and severe signs of Crohn's disease in the rectum. Barium enema examination showed total severe Crohn's colitis with a gastrocolic fistula, suggesting concomitant ileosigmoid fistula. $X$-ray examination of the stomach and small intestine showed a short segment of terminal ileal Crohn's disease in association with total colonic disease, but no evidence of any gastrocolic fistula. Oesophagogastroduodenoscopy showed inflammation and induration at the fistula on the greater curvature of the stomach but no sign of gastric disease.

One week after admission the patient had a laparotomy through a short paramedian incision. After the gastrocolic fistula was found a defunctioning loop ileostomy was performed above the terminal ileal disease. He recovered uneventfully and was discharged ten days later. Within two months he had regained $13.6 \mathrm{~kg}$. The ischiorectal abscesses had completely drained and were dry. Only a small opening remained at the site of the original anal 
fistula without induration. His complaints had disappeared. Three months after operation he had an elective proctocolectomy. At laparotomy not only a gastrocolic but also an ileosigmoid fistula was found. Both fistulas and the entire colon and rectum were removed via the intersphincteric approach for removal of the rectum, though severe rectal inflammation made the procedure difficult. The gastrocolic fistula was also resected, and the patient made an uncomplicated recovery, gaining $30 \mathrm{~kg}$; the perineal wound has healed completely.

\section{Comment}

The diagnosis of granulomatous colitis causing gastrocolic fistula is almost always based on barium enema examination. The fistulous opening is usually so small that it does not show on gastric contrast radiography because the stomach empties preferentially by antral contraction. In our severely malnourished patient-who had been in hospital for a long time-we had the option of using preoperative total parenteral nutrition or performing a simple laparotomy and defunctioning loop ileostomy. Our experience with the latter in debilitated patients had been extremely encouraging, and, although total parenteral nutrition is useful in severely depleted patients, it is expensive, time-consuming, and has complications. Loop ileostomy is simple and easy to perform even in severely ill patients. His recovery in terms of both bowel function and nutrition suggests that this simple technique may be applied more widely.

1 Thoeny RH, Hodgson JR, Scudamore HH. The roentgenologic diagnosis of gastrocolic and gastrojejunocolic fistulas. $A \mathcal{J} R \quad 1960 ; 83: 876-81$.

${ }^{2} \mathrm{McGregor} \mathrm{KH}$. Gastrojejunocolic fistula with associated islet cell tumors of the pancreas. Am $\mathcal{F}$ Surg 1958;96:98-101.

${ }^{3}$ Smith DL, Comer TP. Gastrocolic fistula : a rare complication of benign gastric ulcer. Dis Colon Rectum 1974;17:769-70.

4 Allison JE. Gastrocolic fistula as a complication of gastric lymphoma. Am $\mathcal{F}$ Gastroenterol 1973;59:499-504.

5 Wilk P, Mootaderi F. Gastrocolic fistula complicating transmural colitis: report of a case and review of the literature. Mt Sinai 7 Med NY 1976; 43:525-9.

(Accepted 10 December 1979)

Department of Colon and Rectal Surgery, Cleveland Clinic Foundation, Cleveland, Ohio 44106, USA

A ZAPOLANSKI, MD, surgical resident

D G JAGELMAN, MS, FRCS, staff surgeon spleen is a well-recognised but rare condition. ${ }^{45}$ Nevertheless, the time from her second session of treatment to the onset of symptoms (under four hours) strongly suggests that the ECT was relevant to the development of the ruptured spleen.

I thank Mr J Black, consultant surgeon, and Dr P Hall, consultant psychiatrist (Worcester Royal Infirmary), for their kind permission to report this case.

1 Grossman KLG. Physical treatment of affective disorders. In: Recent advances in clinical psychiatry. London: Churchill, $1971 ; 1: 12-5$.

2 Freeman CPL. Electroconvulsive therapy: its current clinical use. $\mathrm{Br} f$ Hosp Med $1979 ; 21: 281-92$.

${ }^{3}$ Perrin GM. Cardiovascular aspects of electric shock therapy. Acta Psychiatr Scand (Suppl) $1961 ; \mathbf{3 6}: 152$.

4 Atkinson E. Death from idiopathic rupture of the spleen. Br Med 7 1874 ;ii : 403-4.

${ }^{5}$ Bird D, Kelly MJ, Baird RN. Spontaneous rupture of the normal spleen: diagnosis by computerised tomography. Br f Surg 1979;66:598.

(Accepted 10 fanuary 1980)

Worcester Royal Infirmary, Ronkswood Branch, Worcester WR5 1HW

D ERNST, FRCs, surgical registrar

\section{Symptomatic treatment of primary pneumatosis coli with metronidazole}

Pneumatosis coli is a benign condition even though the symptoms may be disabling. Gas cysts are found predominantly in the left side of the colon and the rectum. The condition must be distinguished from secondary pneumatosis cystoides intestinalis, in which subserosal gas is found anywhere in the gastrointestinal tract and its mesentery, and from the infantile type, which is associated with necrotising enterocolitis. The aetiology remains obscure. The two most popular concepts are the pulmonary theory and that of the anaerobic gas-forming organism.

\section{Case reports}

\section{Ruptured spleen after electric convulsion therapy}

Reported injuries in abdominal organs after ECT are rare and include perforation or bleeding from peptic ulcers and perforated viscera. ${ }^{1-3}$ We report here for the first time a ruptured spleen after ECT.

\section{Case report}

A 50-year-old woman suffering from severe endogenous depression was admitted to Newtown Hospital, Worcester, in December 1978 for a course of electric convulsion therapy (ECT). On 18 December she had her first session of treatment without incident, and the second two days later. On both occasions she received $8 \mathrm{ml}(80 \mathrm{mg})$ methohexitone sodium, $13 \mathrm{mg}$ atropine, and $30 \mathrm{mg}$ suxamethonium chloride. Within four hours of her second session of treatment, however, she began to complain of increasingly severe epigastric pain radiating to the back below her scapulae associated with pain in her right shoulder-tip and a worsening acute pain in her abdomen. She had a short history of epigastric discomfort after meals relieved by antacids and exacerbated by fats. There was no history of trauma. A perforated duodenal ulcer was tentatively diagnosed, and she was transferred into the care of a surgical team.

At emergency laparotomy she was found to have several litres of free blood and clots in her peritoneal cavity resulting from a ruptured spleen of normal size. This was subsequently found to be histologically normal. There was no evidence of duodenal ulceration. Splenectomy was performed.

\section{Comment}

This patient presented no history of trauma or splenic disease, and her spleen was histologically normal. Spontaneous rupture of the
(1) A 61-year-old woman presented with a seven-year history of excessive flatus; diarrhoea with excessive mucus, often with incontinence; and vague lower abdominal pain. She also suffered from depression and mild chronic bronchitis. The results of physical examination and sigmoidoscopy were normal. Barium enema showed pneumatosis coli from the mid transverse colon to the rectosigmoid region. These changes were also apparent on plain radiographs. On three occasions she was admitted for oxygen treatment. ${ }^{1}$ Each time her symptoms were relieved for only a few weeks. Finally she was treated with metronidazole $400 \mathrm{mg}$ twice daily. Within two days her symptoms had disappeared completely. Two weeks later the drug was stopped and the symptoms returned gradually over 10 days. Reintroduction of metronidazole again controlled her symptoms although there was little change in her plain abdominal radiographs.

(2) A 72-year-old woman presented with a similar history. In addition she suffered from chronic bronchitis and bronchiectasis. Physical examination revealed the impression of soft "stool-like" masses over the descending colon. Rectal examination suggested the presence of a soft annular carcinoma. Sigmoidoscopy, however, revealed large rectal gas cysts, which were confirmed histologically. Barium enema examination showed extensive cysts in the rectum and colon distal to the hepatic flexure. Treatment with metronidazole $400 \mathrm{mg}$ twice daily immediately relieved her abdominal symptoms. "Remission"' has been maintained by five days' treatment every 2-3 weeks.

\section{Comment}

There is now strong circumstantial evidence that the gas produced in primary pneumatosis coli is of bacterial origin. ${ }^{2-4}$ Despite the frequent association with pulmonary disease the gas has a high hydrogen content and is therefore unlikely to originate from the chest. Lactulose, which depends on bacterial fermentation for its action, is known to aggravate the symptoms. Furthermore, end expiratory concentrations of hydrogen are raised in these patients and are further raised after lactulose challenge. Pulmonary disease may affect the clearance of hydrogen, leading to its accumulation at the site of 